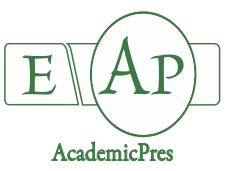

Notulae Botanicae Horti Agrobotanici Cluj-Napoca 48(2):615-625

DOI: $10.15835 /$ nbha 48211940

Research Article

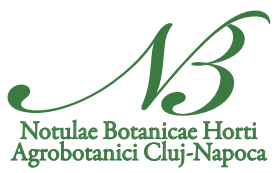

\title{
Natural phytoplasma infections on fruit, vegetable and weed plants at the same agroecosystem and their molecular properties
}

\author{
Hatice D. OKSAL \\ Malatya Turgut Ozal University, Agricultural Faculty, Plant Protection Department, Alacakapı Mahallesi Kırkgöz Caddesi No:70 P.K. \\ 44210 Battalgazi, Malatya, Turkey; digdem.oksal@ozal.edu.tr \\ ORCID:https://orcid.org/0000-0003-1189-7864
}

\begin{abstract}
The phytoplasma associated diseases are an emerging threat to fruit and vegetable crops leading severe yield losses worldwide. Pear (Pyrus communis L.) trees, with symptoms of severe reddening, dwarfing and shoot proliferation were observed in pear orchards of Malatya province of Turkey. Tomato (Solanum lycopersicum L.) plants grown nearby the symptomatic pear orchard displaying leaf rolling, severe flower sterility and purple leaves were observed at the same agroecosystem. To verify the presence and diversity of phytoplasmas, symptomatic pears and tomatoes were sampled and weeds nearby the symptomatic plants were collected. Total plant DNA was purified from midrib of collected leaves using a commercial kit. The DNA samples were analyzed by nested polymerase chain reaction (PCR) using universal primer pairs to amplify $16 \mathrm{~S}$ rDNA fragments. The phytoplasmas detected in collected samples were differed according to the host. Here we detected and characterized 'Candidatus Phytoplasma pyri' belonging to apple proliferation group (subgroup 16SrX-C) from a pear tree, 'Candidatus Phytoplasma trifolii' belonging to clover proliferation group (subgroup 16SrVI-A) from a weed (Amaranthus retroflexus) and 'Candidatus Phytoplasma solani' belonging to the stolbur phytoplasma group (subgroup 16SrXII-A) from a tomato plant. Direct sequencing of PCR products verified the phytoplasmal nature of the infections. The occurrence of ' Ca.P. trifolii' on A. retroflexus is the first report for the world. The irregular presence of the phytoplasmas in fruit and vegetable crops and weeds indicates continuous spread of the phytoplasmas threatening the new crops and new horizons.
\end{abstract}

Keywords: detection and identification; fruit and vegetable crops; phytoplasma; weed

\section{Introduction}

Having no cell wall, phytoplasmas are obligate prokaryotes that belong to Mollicutes class (Lee et al., 2000). Since their discovery in the 1960s, many different phytoplasma diseases have been reviewed affecting different plant species (Lee et al., 2000). They affect annual and perennial crops, bushes and fruit trees, ornamental trees, and natural floras worldwide. They are located in the cytoplasm of plants and insects and they reproduce asexually there (Weintraub and Beanland, 2006). All phytoplasmas are transmitted by phloemfeeding insects, mostly leafhoppers, planthoppers, and psyllids (Bertaccini, 2007). They need plants and insects for survival in nature and they can effectively multiply in both hosts. Phytoplasmas have evolved from a Gram- 
positive Clostridium-like ancestor through genome reductions and loss of outer cell wall. The cells of these bacteria are small but pleiomorphic, averaging $500 \mathrm{~nm}$ in diameter, and are surrounded by a single membrane (Hogenhout, 2009)

A few decades ago, phytoplasmas were detected and identified based on their range of hosts, vectors transmitting them and the symptoms observed on their hosts. However, these methods were troubling and are not appropriate to ascertain the genetic relationship among phytoplasmas (Khan et al., 2002). Today, molecular techniques are used widely for detecting phytoplasmas, in particular, to determine their taxonomic and phylogenetic relationships (Lee et al., 1998a; Lee et al., 2000). Phytoplasmal 16S rRNA gene specific universal primers are used extensively for detecting and identifying the phytoplasmas in plant and their vector insect samples (Smart et al., 1996; Heinrich et al., 2001). Sequencing of the 16S rRNA gene and their in-silico restriction fragment length polymorphism (RFLP) analyses are main techniques currently used for a better identification and characterization of the phytoplasma species and groups (Lee et al., 1998a; Lee et al., 2000).

Turkey is an important vegetable and fruit producer in the World. Phytoplasma associated diseases of fruit trees, vegetable and ornamentals have been reported exhibiting typical symptoms of phytoplasmas in many countries including the United States, India, Australia, Israel, Italy and Jordan (Granett and Provvidenti, 1974; Dale and Smith, 1975; Zimmerman-Gries and Klein, 1978; Varma, 1979; Shaw and Kirkpatrick, 1993; Serrone et al., 2001; Anfoka et al., 2003). In Turkey, phytoplasma diseases have been described in many cultivated crops such as tomato, cucumber, pepper, maize, peach, pear, pomegranates, eggplant, sesame and ornamentals such as marigold (Tagetes erecta L.) (Sertkaya et al., 2007; Ozdemir et al., 2009; Çağlar et al., 2010; Ozdemir and Saygili, 2012; Alp et al., 2016; Gazel et al., 2016, Usta et al., 2017a, Usta et al., 2018a).

The objective of this study was to detect and characterize phytoplasma diseases of pear, tomato and weed samples and their relations to phytoplasmal groups. Here, $16 \mathrm{SrDNA}$ gene sequences of detected phytoplasmas were used to investigate their relations with related phytoplasmas.

\section{Materials and Methods}

\section{Collecting pear, tomato and weed samples}

The plant samples were collected during 2018 and 2019 from Malatya province (Turkey) close to harvest season. The leaf samples of pear and tomato plants with typical or without phytoplasma symptoms and the most common annual weeds (Amaranthus retroflexus, Amaranthus blitoides, Tribulus terrestris, Cirsium arvense, Portulaca oleracea, Xanthium strumarium, Sorghum halepense and Turgenia latifolia) nearby the symptomatic culture plants were sampled during August in 2019. The collected plants were transported to the virology lab in a cool chain for phytoplasma testing.

\section{Isolation of genomic DNA}

DNA samples were prepared from approximately $50 \mathrm{mg}$ of fresh leaf midrib (Lee et al., 1993) using a commercial genomic DNA purification kit (Thermo Scientific, USA) as described by the manufacturer. A ' $\mathrm{Ca}$. Phytoplasma trifolii' isolate of pepper (Capsicum annum L.) from our previous studies from Malatya province, was maintained in the deep freeze and served as a positive source in diagnosis of phytoplasmas by PCR assays. Negative controls were also used obtained from genomic DNAs of asymptomatic pepper and pear.

\section{Amplification and detection of phytoplasmas by Nested-PCR}

Nested-PCR was performed to detect and characterize phytoplasma infections in collected samples. The assay was conducted with a $50 \mu \mathrm{L}$ of reaction mixture volume using universal primer pairs (R16F2n/R16R2 and $\mathrm{R} 16 \mathrm{mF} 2 / \mathrm{R} 16 \mathrm{mR} 1)$. The PCR mixture contained $5 \times \mathrm{PCR}$ reaction buffer $(5.0 \mu \mathrm{L})$, purified sample DNA $(1 \mu \mathrm{L}), 1.5 \mathrm{mM} \mathrm{MgCl} 2,0.25 \mu \mathrm{L}$ of each primer, dNTP mixture (each at $2.5 \mathrm{mM}$ and $1.0 \mu \mathrm{L}$ ) and Taq DNA 
polymerase enzyme $(0.5 \mu \mathrm{L}$, Promega, CA). The first round nested PCR amplicons were diluted 50 times to be used as template for the second step nested reaction. The cycling program of thermocycler (Thermo Scientific Arktik Thermal Cycler, Waltham, MA, USA) was as described by Lee et al. (1993). The amplicons were subjected to electrophorese with $2 \%$ agarose gel and stained with fluorescent nucleic acid gel staining solution (SYBR Safe Gel Stain, ThermoFisher) before visualization under ultraviolet trans-illuminator.

\section{Genomic DNA isolation and weed species identification and PCR amplification}

The fresh leaf tissue of weed samples was used for genomic DNA isolation using a commercial DNA purification kit. The identification of weed species was performed based on the morphological structures and sequence analysis of Internal Transcribed Spacer (ITS) region. The DNA sequence of nuclear ribosomal DNA (nrDNA) were amplified by PCR using ITS4:5'-TCCTCCGCTTATTGATATGC-3' and ITS5: 5'GGAAGTAAAAGTCGTAACAAGG-3' primers (White et al., 1990). PCR reaction was carried out in a final volume of $50 \mu \mathrm{l}$ containing $2 \mu \mathrm{L}$ of purified genomic DNA, $10 \times$ reaction buffer $(5 \mu \mathrm{l}), \mathrm{MgCl} 2(3 \mu \mathrm{l}, 25$ $\mathrm{mM}), \mathrm{dNTPs}(1 \mu \mathrm{l}, 20 \mathrm{mM}$ each), primers $(1 \mu \mathrm{l} 10 \mathrm{pmol}$ of each), DNA polymerase enzyme $(0.4 \mu \mathrm{l})$ and DNase free sterile water $(36.6 \mu \mathrm{l})$. The following PCR cycling was set as described by Keskin et al. (2016). The PCR products were separated on 2\% agarose gel than recovered by using a gel extraction kit (GeneJET Gel Extraction Kit, Thermo Scientific, USA). The DNA fragments were directly sequenced and analyzed by searching in the NCBI database. Nested-PCR assay was performed as described above.

\section{Sequence and phylogenetic analysis}

The 16S rDNA sequences of phytoplasmas in this study were compared with the 16S rDNA sequences of different phytoplasma groups from the NCBI database online. All sequences were aligned and the relationships were assessed using maximum likelihood algorithm of CLC Main Workbench Software (Qiagen, USA) by 1000 bootstrap replicates.

\section{Molecular characterization and in silico digestion of $16 \mathrm{SrDNA}$ sequences}

Molecular variability of detected phytoplasma isolates was studied on the F2n/R2 fragment of 16SrRNA gene. The other $16 \mathrm{~S}$ rRNA gene sequences of apple proliferation group, clover proliferation group and stolbur group were obtained from GenBank. Virtual RFLP patterns of 16S rDNA were obtained using pDRAW32 software. The $16 \mathrm{~S}$ rDNA sequences were digested in silico with 17 different enzymes of restriction reported by Lee et al., (1998b). A virtual agarose gel image of $1.0 \%$ plotted automatically to the computer screen to capture the RFLP pattern of 16Sr DNA sequences using a software (pDRAW32, AcaClone Software).

\section{Results}

\section{Field symptoms}

During the 2018 and 2019 field survey, pear trees and tomato were found to suffer from phytoplasma symptoms. PCR amplificons and in silico RFLP analysis of phytoplasmal 16S rDNA fragments from symptomatic pear, tomato and nearby asymptomatic weed samples revealed the presence of three species of phytoplasmas in sampled plants. The pear sample was found infected by ' $\mathrm{Ca}$. P. pyri' member of the apple proliferation group (subgroup $16 \mathrm{SrX}$ ). The positively reacted pear in the molecular test was apparently symptomatic. The pear sample collected from Malatya exhibited typical symptoms associated with phytoplasmas and had extensive reddening of leaves, shortening of internodes and dwarfing (Figure 1). Both tomato samples tested positive using Nested-PCR and universal phytoplasmal 16 SrRNA specific primers. A tomato and a weed (A. retroflexus) sample were found infected by ' $C a$. P. trifolii' (subgroup 16SrVI-A). The main symptoms of tomato included bush appearance, purplish and rolled leaves, big bud and fruit 
malformation, leaf rolling and reddening, flower sterility, and reduction of plant size (Figure 2). However, no significant symptoms were observed on weed samples including $A$. retroflexus which was found infected. The weeds of $A$. retroflexus, $A$. blitoides, $T$. terrestris, $C$. arvense, $P$. oleracea, $X$. strumarium, $S$. halepense and $T$. latifolia were the most commonly encountered in pear and tomato-producing areas and therefore were the species primarily collected and tested. The species identification of collected weeds was determined based on the morphological structures and by PCR amplification of the ITS region of nuclear ribosomal DNA and sequencing. The remaining tomato sample was found infected by ' $\mathrm{Ca}$. Phytoplasma solani' (16SrXII subgroup A). The main symptoms of tomato observed on ' $\mathrm{Ca}$ P. trifolii' infected plant was similar to that of tomato plants infected by 'Ca. Phytoplasma solani' (Figure 2).

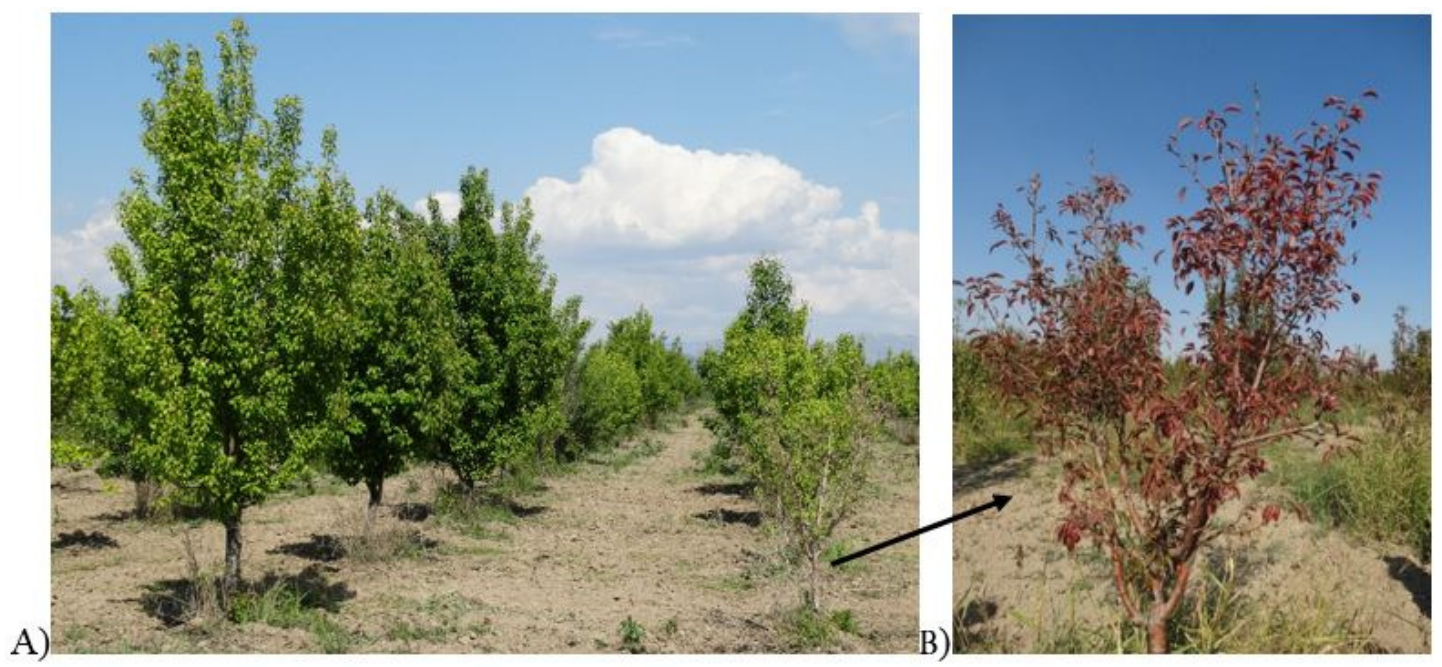

Figure 1. Symptoms of 'Candidatus Phytoplasma pyri' observed on pear in field during 2019 to 2020. A, stunting end yellowing in pear in spring. B, leaf reddening in the same tree in July
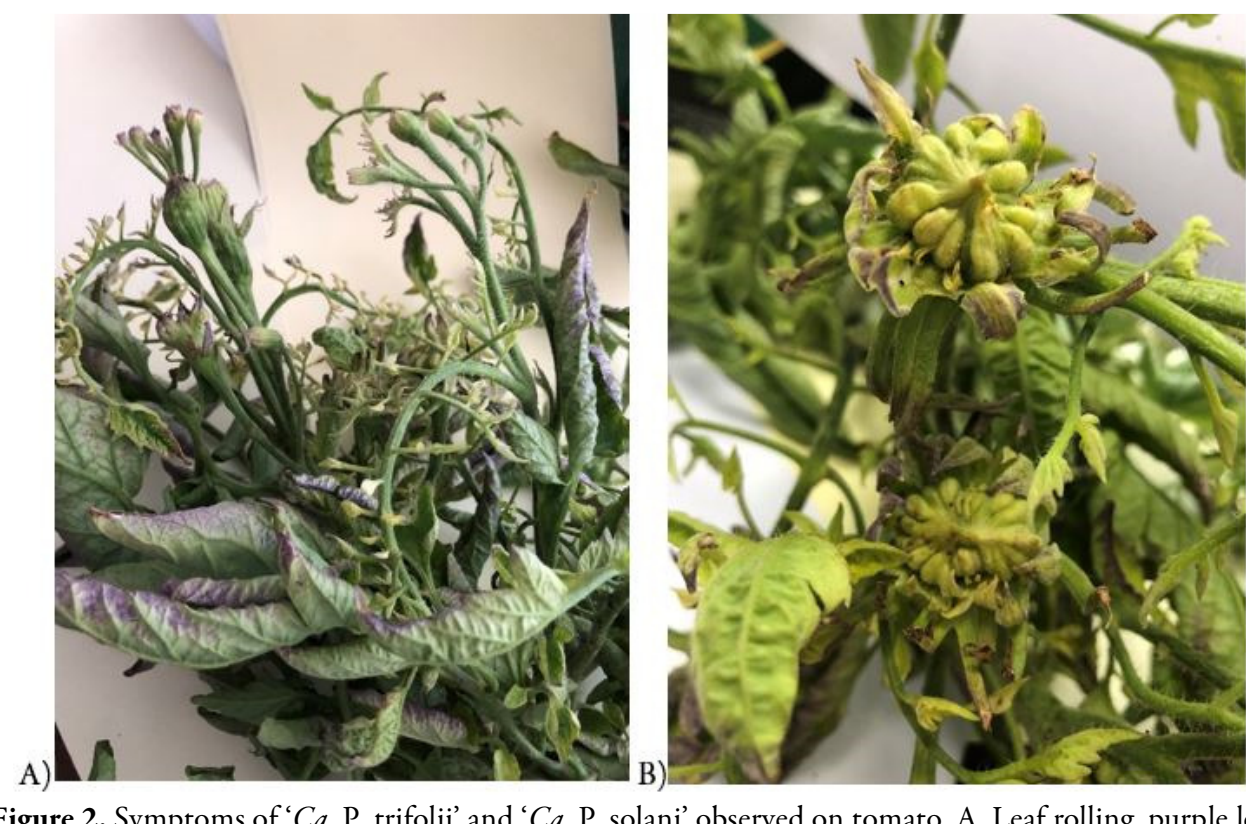

Figure 2. Symptoms of ' $C a$. P. trifolii' and 'Ca. P. solani' observed on tomato. A, Leaf rolling, purple leaf, and big bud symptoms on tomato associated with 'Ca.P. solani'. B, deformed sterile flowers and yellowing on tomato due to ' $\mathrm{Ca}$. P. trifolii' 


\section{Detection and phylogenetic analyses based on $16 S r R N A$ gene}

One pear, two tomatoes and a weed (A. retroflexus) sample were found to be infected by at least one phytoplasmal agent by nested PCR (R16F2n/R16R2). The healthy plants used as negative controls were reacted negative. The nested PCR amplicons of 1,250 bp length (Figure 3) were sequenced and deposited in GenBank with the accession numbers of MT186268, MT186269, MT186270 and MT505687. BLASTn search of detected phytoplama sequences showed a 98,33 to $99,81 \%$ homology with the sequences of $16 \mathrm{~S}$ rDNA sequences of phytoplasmas in the other regions of the world. Even though phytoplasma isolates were collected in the same localities structural sequence variation was detected between the two closely related ' $\mathrm{Ca}$. P. trifolii' isolates. Construction of phylogenetic tree created by the sequences presented in this paper together with three representative strains in $16 \mathrm{SrX}, 16 \mathrm{SrVI}$ and $16 \mathrm{SrXII}$ subgroups and 31 related phytoplasmas from GenBank revealed that the each phytoplasma species clustered at the same clade (Figure 4). However, there phytoplasma species, identified in Malatya, clustered together forming a monophyletic group.

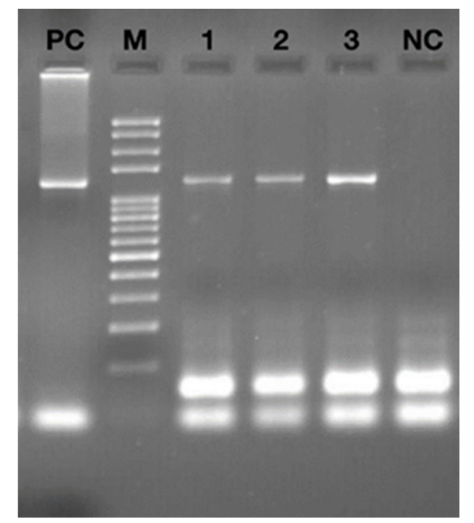

Figure 3. Agarose gel electrophoresis of PCR products amplified from phytoplasma infected plants. PC, positive control, M, 1 kb DNA ladder, 2 'Ca. P. pyri', 2 ' Ca. P. solani', 3 ' Ca. P. trifolii', NC negative control

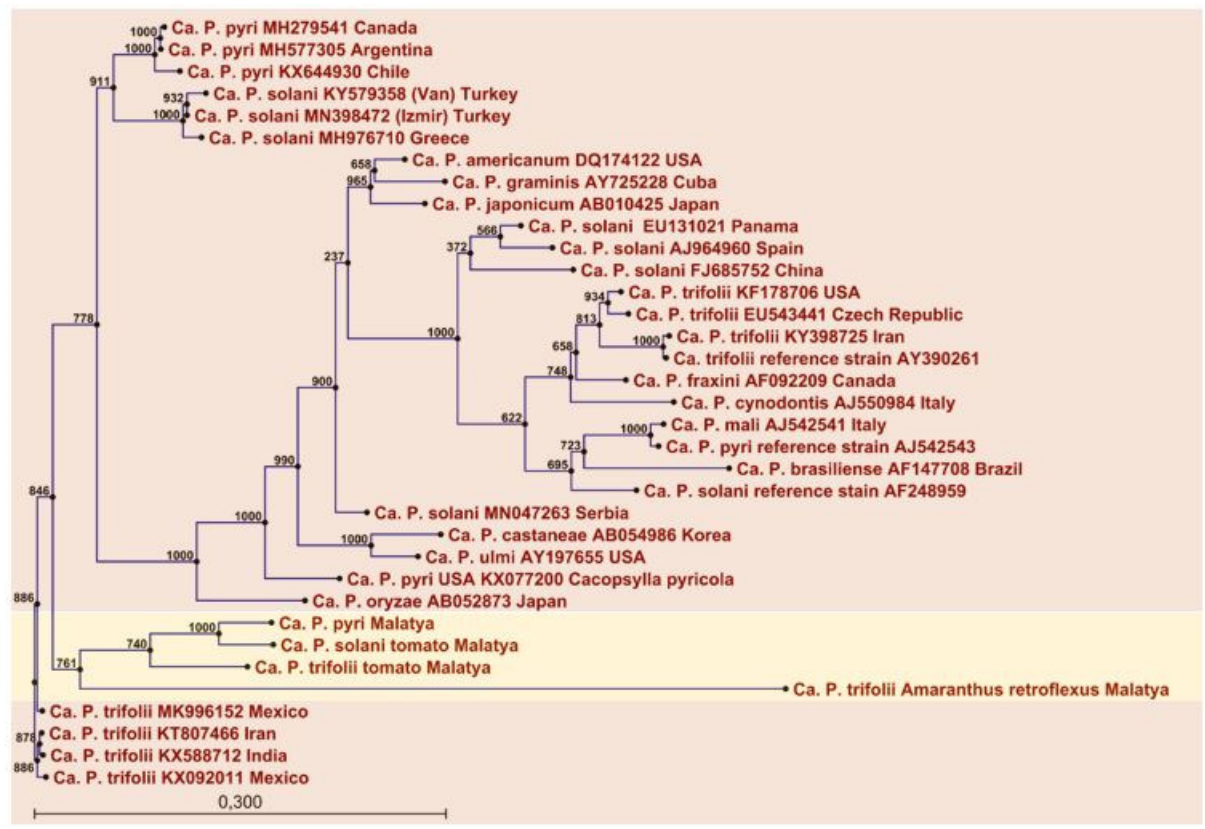

Figure 4. Phylogenetic tree constructed by maximum likelihood algorithm using 16S rDNA sequences from reference phytoplasma strains in 16SrX, 16SrVI and 16SrXII subgroups and other 16Sr phytoplasma groups with 1000 replicates. Isolates highlighted were obtained from Malatya used in this study 
BLASTn search for sequence similarity revealed that three different phtoplasma species ' $C a$. P. pyri', 'Ca. P. trifolii' and 'Ca. P. solani' share 99.81-99.43\%, 98.78-98.33\% and 99.81-99.90\% sequence similarity with sequences those recorded in GenBank, respectively (Table 1).

Table 1. Accession numbers and geographical origins of phytoplasma strains used in comparison and phylogenetic tree in this study

\begin{tabular}{|c|c|c|}
\hline Phytoplasma name & Geographic origin & Accession number \\
\hline 'Ca.P. japonicum' & Japan & AB010425 \\
\hline 'Ca. P. castaneae' & Korea & $\mathrm{AB} 054986$ \\
\hline 'Ca. P. fraxini' & Canada & AF092209 \\
\hline 'Ca. P. brasiliense' & Brazil & AF147708 \\
\hline 'Ca. P. solani' & USA & AF248959 \\
\hline 'Ca.P. mali' & Italy & AJ542541 \\
\hline 'Ca. P. pyri' & Germany & AJ542543 \\
\hline 'Ca. P. cynodontis' & Italy & AJ550984 \\
\hline 'Ca. P solani' & Spain & AJ964960 \\
\hline 'Ca. P. ulmi' & USA & AY197655 \\
\hline 'Ca. P. trifolii' & Canada & AY390261 \\
\hline 'Ca. P. graminis' & Cuba & AY725228 \\
\hline 'Ca. P. americanum' & USA & DQ174122 \\
\hline 'Ca. P. solani' & Panama & EU131021 \\
\hline 'Ca. P. trifolii' & Czech Republic & EU543441 \\
\hline Apple stolbur phytoplasma & China & FJ685752 \\
\hline 'Ca. P. trifolii' & USA & KF178706 \\
\hline 'Ca. P. trifolii' & Iran & KT807466 \\
\hline 'Ca.P. pyri & USA & KX077200 \\
\hline 'Ca. P. trifolii & Mexico & KX092011 \\
\hline 'Ca. P. trifolii' & India & KX588712 \\
\hline 'Ca.P. pyri' & Chile & KX644930 \\
\hline 'Ca. P. trifolii' & Iran & KY398725 \\
\hline 'Ca. P. solani' & Van (Turkey) & KY579358 \\
\hline 'Ca. P. pyri' & Canada & MH279541 \\
\hline 'Ca. P. pyri' & Argentina & MH577305 \\
\hline 'Ca. P. solani' & Greece & MH976710 \\
\hline 'Ca. P. trifolii' & Mexico & MK996152 \\
\hline 'Ca. P. solani' & Serbia & MN047263 \\
\hline 'Ca. P. solani' & İzmir (Turkey) & MN398472 \\
\hline
\end{tabular}

The restriction profiles of species 'Ca. P. pyri', 'Ca. P. trifolii' and ' $C a$. P. solani' and reference strains are shown in Figure 4. In silico RFLP analysis of $16 \mathrm{~S}$ rDNA F2nR2 fragment revealed a variation in 'Ca. P. trifolii' tomato D2 isolate comparing with the reference strain in Hhal profiles (Figure 4). However, the virtual RFLP analyses of $16 \mathrm{~S}$ rDNA F2nR2 fragment of species ' $\mathrm{Ca}$. P. pyri' (Acces. no: MT186268) and 'Ca. Phytoplasma solani' (Acces. no: MT186270) with seventeen restriction enzymes resulted in identical restriction patterns to the reference pattern of $16 \mathrm{Sr}$ X subgroup C and 16Sr XII subgroup A, respectively (Figure 5). 


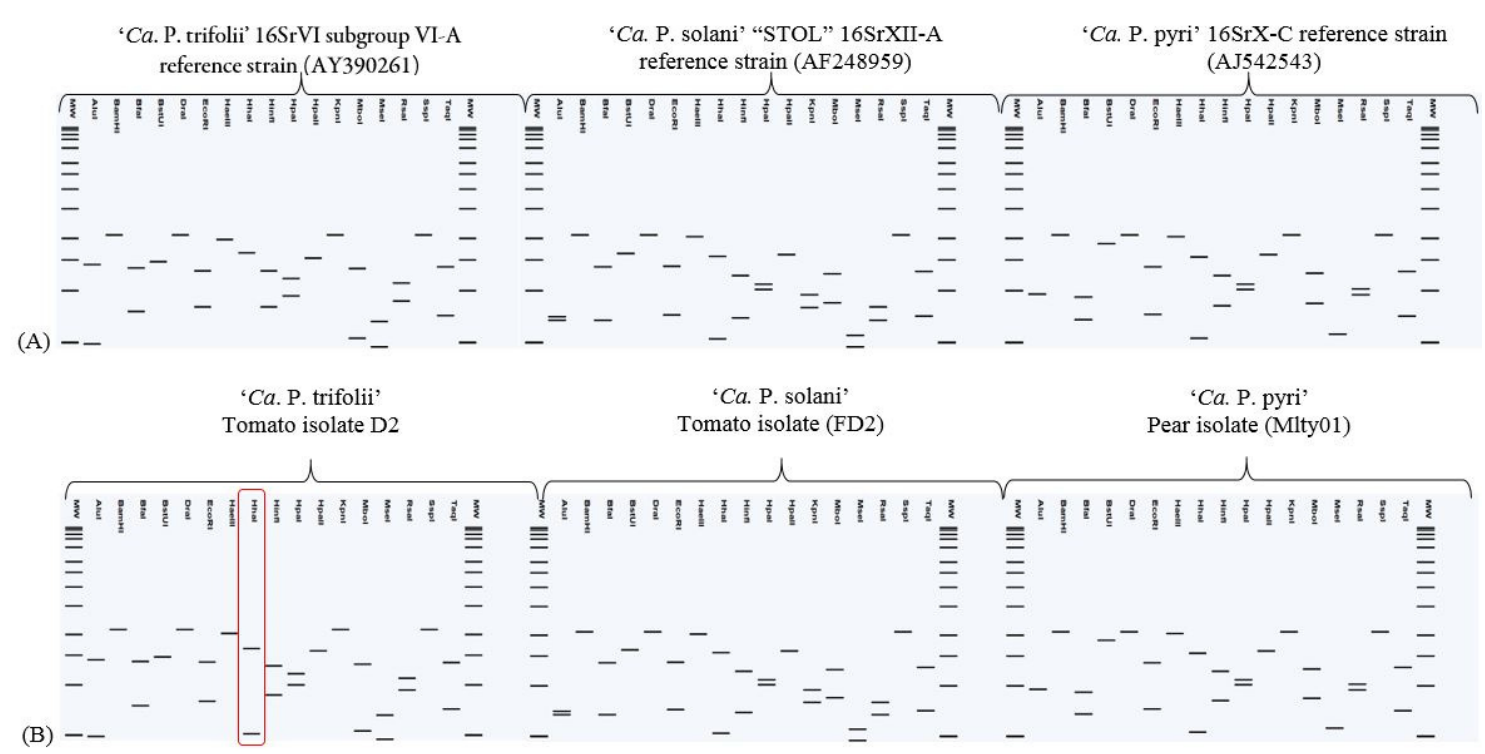

Figure 5. Virtual RFLP patterns of pear-associated 'Ca. P. pyri’ Malatya (Acces N: MT186268), tomatoassociated 'Ca. P. solani' FD2 (Acces N: MT186270), 'Ca. P. trifolii’ D2 (Acces N: MT186269) and $A$. retroflexsus-associated ' $C a$. P. trifolii'B8 (MT505687) and representative strains of 'Ca. P. pyri' $16 \mathrm{SrX}$ subgroup C (AJ542543), 'Ca. P. trifolii' 16SrVI subgroup A (AY390261) and 'Ca. P. solani' "STOL" 16SrXII subgroup A (AF248959). Simulated in silico digestion of the $16 \mathrm{~S}$ rDNA R16F2n/R2 fragments of phytoplasma species identified in Malatya and reference strains of $16 \mathrm{Sr}$ phytoplasma groups. The box indicates the difference in restriction patterns of the isolate. MW: $1 \mathrm{~kb}$ DNA molecular weight marker.

\section{Discussion}

In Malatya, ' $C a$. P. pyri', 'Ca. P. trifolii' and 'Ca. P. solani' are the most recent phytoplasmal pathogens to be found infecting commercial pear and tomato that can cause economic damage to these crops. ' $\mathrm{Ca}$. P. trifolii' and ' $\mathrm{Ca}$. P. solani' are considered the most destructive phytoplasmas infecting fruits and vegetables that have pleomorphic cells, and are transmitted by leafhoppers efficiently (Marcone et al., 1997). Symptoms of severe stunting, general chlorosis in spring and leaf reddening in mid-summer of the entire pear tree may be due to high level virulence of ' $C a$. P. pyri' strain involved or due to high-level of susceptibility of infected host. This phytoplasma was first reported on pears in Turkey from Adana and Hatay (Sertkaya et al., 2005), and subsequently from Bursa (Serçe et al., 2006; Gazel et al., 2007) and Isparta and Ankara (Orel et al., 2019) provinces. Severe and indistinguishable symptoms of phytoplasmas were observed in tomato plants including big bud, leaf rolling, stunting, purple leaf, flower sterility and malformation. In a previous field survey done in the summer of 2016 in Malatya, 'Ca. P. trifolii' infections were found in pepper plants (Oksal et al., 2017). Our results suggest that both phytoplasma infections are not epidemic in commercial vegetable fields in Malatya, consistent with the limited or no activity of these vectors in the area. There are published recent reports on ' $\mathrm{Ca}$. P. solani' infection of vegetables in the world. This pathogen was previously reported to infect tomatoes naturally as well as at least 100 plant species from 40 families (Yaman 1971; Reckhaus et al., 1988; Özdemir et al., 2009).

Like other weed samples, ' $C a$. P. trifolii' infected $A$. retroflexus showed no suggestive symptoms of phytoplasma infection. 'In the present study, a new species of common weed, $A$. retroflexus, has been detected to harbor ' $C a$. P. trifolii' in Turkey. To our knowledge, this is the first report of ' $C a$. P. trifolii' on $A$. retroflexus in the world. It was concluded that $A$. retroflexus may serve as alternative host for phytoplasma infestations. It 
was concluded that $A$. retroflexus may serve as alternative host for phytoplasma infestations. Until now, a very few weedy hosts (Calotropis gigantea, Datura inoxia and D. stramonium L.) have been reported containing ' Ca. P. trifolii' infection (Raj et al., 2009; Priya et al., 2010). Amiri Mazraie et al. (2108) identified 'Ca. P. trifolii' in rapeseed (Brassica napus). They observed phytoplasma-associated symptoms on rapeseed like stunting, witches' broom and little leaves in Iran.

In the phylogeny inferred from ribosomal DNA sequences, the all pathogenic phytoplasma species identified in Malatya clustered together within the same clade, forming a monophyletic group. Except for $A$. retroflexsus, the absence of ' $\mathrm{Ca}$. P. trifolii' in the weeds tested, indicates that it can be found in other surviving weedy hosts for its epidemiology which has not been tested.

For the species-level confirmation of local isolates belonging to $16 \mathrm{SrX}, 16 \mathrm{SrVI}$ and $16 \mathrm{SrXII}$ subgroups on the basis of virtual RFLP analysis were performed using the 16S rRNA gene F2nR2 fragments. These fragments were subjected to in silico digestion with seventeen restriction enzymes on $1 \%$ agarose gel electrophoresis. Detected phytoplasma isolates displayed similar RFLP patterns compared with reference strains, except ' $\mathrm{Ca}$. P. trifolii' D2 tomato isolate which differed by at least one band (Figure 4). It has been shown that as few as one restriction site difference within the phytoplasmal $16 \mathrm{~S}$ rRNA gene F2nR2 fragment may qualify the strain to be recognized (Lee et al., 1993, 1998a, 2000). However, for the accurate analysis, the 16S rRNA gene-based phytoplasma classification scheme should be supported by automated similarity coefficient calculation and computer-simulated RFLP analysis (Wei et al., 2007a; Wei et al., 2007b; Lee et al., 2007). The representative members (reference strains) should show at least $97 \%$ of RFLP pattern similarity. Virtual RFLP analysis of phytoplasmal 16S rRNA gene F2nR2 fragments of Malatya isolates generated distinct RFLP patterns between ' $C a$. P. trifolii' D2 isolate and reference strain of the same species indicating genetic diversity of tomato isolate. They were differed only by the HhaI digestion profiles given in Figure 4 . The results showed that tomato D2 isolate of ' $\mathrm{Ca}$. P. trifolii' was more diverse than those of ' $\mathrm{C}$. P. trifolii'. Occurrence of variants of ' $C a$. P. trifolii' has long been known through studies on genetic interaction between this phytoplasma and vegetable crops such as pepper (Oksal et al., 2017).

The occurrence of the phytoplasmas is not new in Turkey since there are earlier and recent reports of some hosts (Sertkaya et al., 2007; Ikten et al., 2014; Gazel et al., 2015; Usta et al., 2017b, Usta et al., 2018b; Usta et al., 2020). The results of the present study showed that the symptoms of stunting, yellowing, reddening of pear plant and the flower sterility, malformation, big bud and dwarfing of tomato plants collected were all associated with phytoplasmas. There are no documented occurrences in Malatya of detected phytoplasmas, including 'Ca. P. pyri' in pear, 'Ca. P. solani' in tomato and in $A$. retroflexus and 'Ca. P. trifolii' in tomato. However, further studies of the insect transmission, biological and molecular properties of different ' $\mathrm{C} a$. $\mathrm{P}$. pyri', 'Ca. P. trifolii' and 'Ca. P. solani' isolates in Malatya province may reveal new information among isolates of these phytoplasmas. Additional studies should be performed to assess the distribution, insect vectors and economic impact of three phytoplasma species in fruit and vegetable plantations. Although the phytoplasma diseases are common in Turkey, this research is the first report from the association of ' $\mathrm{Ca}$. P. pyri' with pear, 'Ca. P. solani' with tomato, 'Ca. P. trifolii' with tomato and A. retroflexus in Malatya.

\section{Acknowledgements}

I thank Prof. Dr. Nihat TURSUN (Malatya Turgut Ozal University) for the morphological identification of the weed species used in this study. 
Oksal HD (2020). Not Bot Horti Agrobo 48(2):615-625

\section{Conflict of Interests}

The author declares that there are no conflicts of interest related to this article.

\section{References}

Alp Ş, Usta M, Sipahioğlu HM, Güller A (2016). First report of “Candidatus Phytoplasma solani” on a new host marigold (Tagetes erecta L.) Turkish Journal Agriculture and Forestry 40:311-318. https://doi:10.3906/tar-1506-58

Amiri MM, Faghihi MM, Samavi S, Askari SM, Bagheri A, Rowshan GH (2018). First report of a 'Candidatus Phytoplasma trifolii'-related strain associated with rapeseed witches' broom in Iran. New Disease Reports 38:19. http://dx.doi.org/10.5197/j.2044-0588.2018.038.01

Anfoka GH, Khalil AB, Fattash I (2003). Detection and molecular characterization of a phytoplasma associated with big bud disease of tomatoes in Jordan. Journal of Phytopathology 151(4):223-227. https://doi:10.1046/j.14390434.2003.00709.x

Çağlar BK, Elbeaino T, Küsek M, Pehlivan D, Fidan H, Portakaldalı M (2010). Stolbur phytoplasma infections in potato and tomato plants from different locations in Turkey. Journal of Turkish Phytopathology 39:1-3.

Bertaccini A (2007). Phytoplasmas: diversity, taxonomy, and epidemiology. Frontiers Bioscience 1:12:673-89.

Dale JL, Smith LD (1975). Mycoplasmalike bodies observed in tomato plants with big bud in Arkansas. Plant Disease Reporter 59:455-458.

Gazel M, Ulubaş Serçe, Ç, Çağlayan K, Öztürk H (2007). Detection of 'Candidatus Phytoplasma pyri' in Turkey. Bulletin of Insectology 60(2):125-126.

Gazel M, Çaglayan K, Baspinar H, Mejia JF, Paltrinieri S, Bertaccini A, Contaldo N (2015). Detection and identification of phytoplasmas in pomegranate trees with yellows symptoms. Journal of Phytopathology 164:136-140. https://doi.org/10.1111/jph.12401

Gazel M, Çağlayan K, Başpınar H, Mejia JF, Paltrinieri S,Bertaccini A,Contaldo N (2016). Detection and identification of phytoplasmas in pomegranate trees with yellows symptoms. Journal of Phytopathology 164:136-140.

Granett AL, Provvidenti R (1974). Tomato big bud in New York State. Plant Disease Reporter 58:211-214.

Heinrich M, Simona B, Caprara L, Arthofer W, Strommer S, Hanzer V, ... da Câmara Machado ML (2001). Improved detection method for fruit tree phytoplasmas. Plant Molecular Biology Reporter 19:169-179.

Hogenhout SA (2009) Plant pathogens, minor (Phytoplasmas). In: Schaechter M (Ed). Encyclopedia of Microbiology (Third Edition), Academic Press, San Diego, USA, pp 678-688 https://doi.org/10.1016/B978-0123739445.00348-5.

Ikten C, Catal M, Yol E, Ustun R, Furat S, Toker C, Uzun B (2014). Molecular identification, characterization and transmission of phytoplasmas associated with sesame phyllody in Turkey. European Journal of Plant Pathology 139: 217-229. https://doi 10.1007/s10658-014-0384

Keskin F, Kaya I, Usta M, Demir I, Sipahioglu HM, Nemli Y (2017). Molecular cloning and sequence analysis of the its region of nuclear ribosomal DNA for species identification in dodders (Cuscuta; Convolvulaceae). International Journal of Agriculture and Biology 19:1447-1451.

Khan AJ, Botti S, Al-Subhi AM, Gundersen-Rindal DE, Bertaccini AF (2002). Molecular identification of a new phytoplasma associated with alfalfa witches'-broom in Oman, Phytopathology 92(10):1038-47. https://doi: 10.1094/PHYTO.2002.92.10.1038

Lee IM, Hammond RW, Davis RE, Gundersen DE (1993). Universal amplification and analysis of pathogen 16S rDNA for classification and identification of mycoplasmalike organism. Phytopathology 83:834-842.

Lee IM, Gundersen-Rindal DE, Davis RE, Bartoszyk IM (1998a). Revised classification scheme of phytoplasmas based on RFLP analysis of $16 \mathrm{~S}$ rRNA and ribosomal protein gene sequences. International Journal of Systematic Bacteriology 48:1153-1169.

Lee IM, Gundersen-Rindal DE, Bertaccini A (1998b). Phytoplasma: ecology and genomic diversity. Phytopathology 88:1359-1366.

Lee IM, Davis RE, Gundersen-Rindal DE (2000). Phytoplasma: phytopathogenic mollicutes. Annual Review of Microbiology 54:221-255. 
Lee IM, Zhao Y, Davis RE, Wei W, Martini M (2007). Prospects of DNA-based systems for differentiation and classification of phytoplasmas. Bulletin of Insectology 60:239-244.

Marcone C, Ragozzino A, Seemuller E (1997). Detection and identification of phytoplasmas in yellows-diseased weeds in Italy. Plant Pathology 46:530-537.

Oksal HD, Apak Kaya F, Oksal E, Tursun N, Sipahioglu HM (2017). Detection and molecular characterization of two 'Candidatus Phytoplasma trifolii' isolates infecting peppers at the same ecological niche. International Journal of Agriculture and Biology 19(6):1372-1378. https://doi:10.17957/IJAB/15.0420

Orel Canik D, Paltrinieri S, Ertunç F, Bertaccini A (2019). Molecular diversity of 'Candidatus Phytoplasma' species in pome and stone fruits in Turkey. Plant Protection Bulletin 59(1):7-14. https://doi.org/10.16955/bitkorb.508890.

Özdemir N, Saygılı H (2012). Batı Anadolu Bölgesi domates üretim alanlarında görülen stolbur hastalığının tohumla taşınıp taşınmadığı ile ilgili bir araştırma [A study on the transmission with the seed of stolbur disease in Western Anatolia tomato areas]. Journal of Agricultural Faculty of Uludag University 26(1):63-72.

Özdemir N, Saygılı H, Sahin F, Karsavuran Y, Bayrak O F, Oral B (2009). Host range and genetic characterization of a phytoplasma causing tomato stolbur disease in Turkey. Acta Horticulturae 808:255-262.

Priya M, Chaturvedi Y, Rao GP, Raj SK (2010). First report of phytoplasma 'Candidatus Phytoplasma trifolii' (16Sr VI) group associated with leaf yellows of Calotropis gigantea in India. New Disease Reporter 22:29. http://dx.doi.org/10.5197/j.2044-0588.2010.022.029

Raj SK, Snehi SK, Kumar S, Khan MS (2009). First finding of' Candidatus Phytoplasma trifolii' (16SrVI group) associated with little leaf disease of Datura inoxia in India. Plant Pathology 58:791. https:// doi:10.1111/j.13653059.2009.02053.x

Reckhaus P, Reckhaus S, Adamou I (1988). Stolbur disease of tomato plants in Niger. Plant Disease 72(3):268.

Serçe Ç, Gazel M, Çaglayan K, Baş, M, Son, L (2006). Phytoplasma diseases of fruit trees in germplasm and commercial orchards in Turkey. Journal of Plant Pathology 88 (2):179-185.

Serrone P, Marzachì C, Bragaloni M, Galeffi P (2001). Phytoplasma infection of tomato in central Italy. Phytopathologie Mediterrenea 40:137-142.

Sertkaya G, Martini M, Ermacora P, Musetti R, Osler R (2005).Detection and characterization of phytoplasmas in diseased stone fruits and pear by PCR-RFLP analysis in Turkey. Phytoparasitica 33:380-390.

Sertkaya G, Martini M, Musetti R, Osler R (2007). Detection and molecular characterization of phytoplasmas infecting sesame and solanaceous crops in Turkey. Bulletin of Insectology 60(2):141-142.

Shaw ME, Kirkpatrick BC, Golino DA (1993). The beet leafhopper-transmitted virescence agent causes tomato big bud disease in California. Plant Disease 77:290-295.

Smart CD, Schneider B, Blomquist NCL, Guerra LJ, Harrison NA, Ahrens U, ... Kirckpatrick BC (1996). Phytoplasmaspecific PCR primers based on sequences of the 16S-23S rRNA spacer region. Applied and Environmental Microbiology 62:2988-2993.

Usta M, Güller A, Sipahioğlu HM (2017a). Detection and characterization of two phytoplasma lineages on cucumber (Cucumis sativus $\mathrm{L}$ ) with same symptomatology based on virtual RFLP and nucleotide sequence analysis of $16 \mathrm{~s}$ rDNA. Yüzüncü Yll University Journal of Agricultural Sciences 27:299-308.

Usta M, Güller A, Sipahioğlu HM (2017b). Characterization and identification of important phytoplasma diseases in Solanacea family in Van province. II. International Igdir Symposium, 9-10 October Iğdır/Turkey.

Usta M, Güller A, Sipahioglu HM (2018a). Molecular analysis of 'Candidatus Phytoplasma trifolii' and 'Candidatus Phytoplasma solani' associated with phytoplasma diseases of tomato (PDT) in Turkey. International Journal of Agriculture and Biology 20:1991-1996.

Usta, M, Güller A, Sipahioğlu HM (2018b). Türkiye'de 'Canditatus Phytoplasma trifolii’ için yeni bir konukçu olan armut (Pyrus Communis L.)'taki izolatlarının moleküler karakterizasyonu [Molecular characterization of 'Canditatus Phytoplasma trifolii' isolates of pear, a new host for Turkey]. I. International Iğdır Congress on Multidisciplinary Studies. November, 2018 Igdir/Turkey.

Usta M, Güller A, Sipahioğlu HM (2020). Detection, in silico analysis and molecular diversity of phytoplasmas from solanaceous crops in Turkey. Pakistan Journal of Botany. (In press).

Varma JP (1979) Occurrence of tomato big bud like disease in Haryana. Science and Culture 45:205-207.

Wei W, Davis RE, Lee IM, Zhao Y (2007a). Computer simulated RFLP analysis of 16S rRNA genes: identification of ten new phytoplasma groups. International Journal of Systematic and Evolutionary Microbiology 57:1855-1867. 
Wei W, Lee I-M, Davis RE, Suo X, Zhao Y (2007b). Virtual RFLP analysis of 16 rDNA sequences identifies new subgroups in the clover proliferation phytoplasma group. Bulletin of Insectology 60:349-350.

Weintraub PG, Beanland LA (2006). Insect vectors of phytoplasmas. Annual Review of Entomology 51:91-111 https://doi: 10.1146/annurev.ento.51.110104.151039

White TJ, Bruns T, Lee S, Taylor JW (1990). Amplification and direct sequencing of fungal ribosomal RNA genes for phylogenetics. In: Innis MA, Gelfand DH, Sninsky JJ, White TJ, editor.PCR Protocols: A Guide to Methods and Applications.New York: Academic Press Inc; pp 315-322.

Yaman IKA (1971). Tomato stolbur virus: a new record. FAO Plant Protection Bulletin 19(6):140-141.

Zimmermann-Gries S, Klein M (1978). A tomato big bud-like disease of tomatoes in Israel and its association with mycoplasmalike organisms. Plant Disease Reporter 62:590-594.

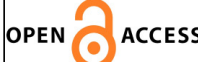

(c)
The journal offers free, immediate, and unrestricted access to peer-reviewed research and scholarly work. Users are allowed to read, download, copy, distribute, print, search, or link to the full texts of the articles, or use them for any other lawful purpose, without asking prior permission from the publisher or the author.

License - Articles published in Notulae Botanicae Horti Agrobotanici Cluj-Napoca are Open-Access, distributed under the terms and conditions of the Creative Commons Attribution (CC BY 4.0) License. (c) Articles by the authors; UASVM, Cluj-Napoca, Romania. The journal allows the author(s) to hold the copyright/to retain publishing rights without restriction. 